Review article

\title{
Immunological biomarkers identifying natalizumab-treated multiple sclerosis patients at risk of progressive multifocal leukoencephalopathy
}

\author{
Federico Serana ${ }^{\mathrm{a}}$, Marco Chiarini ${ }^{\mathrm{a}}$, Alessandra Sottini ${ }^{\mathrm{a}}$, Diego Bertoli ${ }^{\mathrm{a}}$, Viviana Giustini ${ }^{\mathrm{a}}$, \\ Marion Vaglio Tessitore ${ }^{a}$, Luigi Caimi ${ }^{a}$, Ruggero Capra ${ }^{b}$, Luisa Imberti ${ }^{a, *}$ \\ a Centro di Ricerca Emato-oncologica AIL (CREA), Diagnostics Department, Spedali Civili of Brescia, Italy \\ ${ }^{b}$ Multiple Sclerosis Center, Spedali Civili of Brescia, Italy
}

\section{A R T I C L E I N F O}

\section{Article history:}

Received 26 August 2014

Received in revised form 27 October 2014

Accepted 29 October 2014

\section{Keywords:}

Multiple sclerosis

Natalizumab

Progressive multifocal leukoencephalopathy

T-cell receptor excision circles

K-deleting recombination excision circles

T-cell receptor repertoire

\begin{abstract}
A B S T R A C T
Natalizumab-induced progressive multifocal leukoencephalopathy appears to be unleashed by complex interactions between viral and immunological host factors leading the latent form of JC virus to become pathogenic. Positive anti-JC virus antibody status, prior use of immunosuppressants, and increasing duration of natalizumab treatment have been proposed as risk factors for progressive multifocal leukoencephalopathy in multiple sclerosis patients, but while they may help to identify the most appropriate patients for natalizumab, their use have some limitations. Therefore, a large body of studies is ongoing to identify alternative, reliable immunological markers capable to improve the safety and efficacy of therapy, and to guide tailored clinical decisions.
\end{abstract}

(c) 2014 Elsevier B.V. All rights reserved.

\section{Contents}

1. Introduction ...................................................6

2. Known predictive markers for natalizumab-related PML . . . . . . . . . . . . . . . . . . . . . . . . . . . . . . . . . . . . . . . . . . . 7

3. Proposed alternative, immunological markers predictive of natalizumab-related PML . . . . . . . . . . . . . . . . . . . . . . . 7

3.1. Anti-JCV neutralizing activity .... . . . . . . . . . . . . . . . . . . . . . . . . . . . . . . . . . . 7

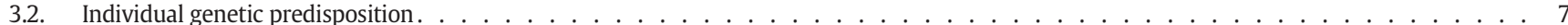

3.3. Bioenergetic values in immune cells . . . . . . . . . . . . . . . . . . . . . . . . . . . . . . . . . . . . . . . . . . . . . 8

3.4. IL-10 production by $\mathrm{CD} 4^{+} \mathrm{T}$ cells. . . . . . . . . . . . . . . . . . . . . . . . . . . . . . . . . . . . . . . . . . . . . . 8

3.5. Blood microRNA expression pattern . . . . . . . . . . . . . . . . . . . . . . . . . . . . . . . . . . . . . . . . 8

3.6. L-selectin (CD62L) percentage on CD4 ${ }^{+} \mathrm{T}$ cells . . . . . . . . . . . . . . . . . . . . . . . . . . . . . . . . . . . . . . . . . . 9

3.7. Newly produced $\mathrm{T}$ and $\mathrm{B}$ lymphocytes and T-cell repertoire diversity . . . . . . . . . . . . . . . . . . . . . . . . . . . . . . . . . 9

4. Conclusions. . . . . . . . . . . . . . . . . . . . . . . . . . . . . . . . . . . . . . . . . . . 10

References. . . . . . . . . . . . . . . . . . . . . . . . . . . . . . . . . . . . . 10

Abbreviations: CDR3, complementarity-determining region-3; CNS, central nervous system; CSF, cerebrospinal fluid; iATP, intracellular ATP concentration; JCV, JC virus; KRECs, K-deleting recombination excision circles; miRNA, microRNA; MRI, magnetic resonance imaging; MS, multiple sclerosis; PCR, polymerase chain reaction; PML, progressive multifocal leukoencephalopathy; TCRBV, T-cell receptor V beta family; TRECs, T-cell receptor excision circles.

* Corresponding author at: CREA, Diagnostics Department, Spedali Civili of Brescia, p.le Spedali Civili 1, 25123 Brescia, Italy. Tel.: + 39030 3995408; fax: + 390303996001.

E-mail address: limberti@yahoo.it (L. Imberti).

\section{Introduction}

Several disease-modifying therapies that appear to be more efficacious than interferon beta $1 \mathrm{~b}$, which was the first drug proven to be effective in altering the natural history of the disease (The IFNB Multiple Sclerosis Study Group, 1993; Karussis, 2013), have been recently proposed for the treatment of relapsing-remitting multiple sclerosis (MS). The so far approved disease-modifying drugs, although showing variable efficacy in reducing relapse risk and preserving neurological 
functions, differ in tolerability, likelihood of treatment adherence, risk of major toxicity, and are associated to adverse effects of variable severity (Wingerchuk and Carter, 2014).

Thus, the benefit-to-risk ratio for each alternative treatment must be carefully evaluated at multiple levels when a therapeutic strategy has to be chosen. Several factors should be taken into account for the prescription of immunoactive drugs, such as severity and worsening of the disease, patient's concern about present or future symptoms and disability, patient's tolerance to side effects, availability of other therapeutic options, and existence of biomarkers identifying patients at higher risk of developing severe adverse reactions. This is particularly urgent for patients at risk to develop progressive multifocal leukoencephalopathy (PML) because of natalizumab treatment. In fact, as of the 31st of May 2014, 474 cases of natalizumab-associated PML have been described (http://multiple-sclerosisresearch.blogspot.it/2014/07/clinic-speaknatalizumab-pml-update.html).

The present article reviews some biomarkers that have been proposed to evaluate the safety of natalizumab therapy as well as the most promising results in this field.

\section{Known predictive markers for natalizumab-related PML}

PML is a demyelinating brain disease caused by the JC virus (JCV) (Brew et al., 2010). JCV infection is frequently acquired during childhood; afterwards, the virus persists in the body in a latent state, replicating at low levels only episodically (Hou and Major, 2000; Khalili et al., 2008). PML, which was initially diagnosed mainly in patients with AIDS or lymphoproliferative disease (Calabrese et al., 2007), is now also observed during therapy with a variety of immunomodulating drugs, natalizumab being the most frequently implicated, especially in patients without an underlying predisposing condition (Carson et al., 2009; Schmedt et al., 2012; Piccinni et al., 2013). As of September 2, 2014, the overall incidence of PML in natalizumabtreated patients is 3.72 per 1000 patients (http://www.biogenidecinternational.com/tysabri.aspx? ID =4763; accessed October 24, 2014). While in severely immunosuppressed patients PML is often fatal (Tan and Koralnik, 2010), the disease developing under natalizumab is not always lethal, with an overall mortality of $22 \%$ (http://www.biogenidecinternational.com/tysabri.aspx? ID =4763; accessed October 24, 2014), mostly due to the PML immune reconstitution inflammatory syndrome (Clifford et al., 2010). The majority of survivors of natalizumabassociated PML are left with a moderate-to-severe disability, depending on the location more than on the size of lesions, the most serious ones being in the brainstem (Clifford et al., 2010).

In MS patients, an early diagnosis of PML in an asymptomatic phase is crucial because it is associated with better clinical outcomes (Wattjes et al., 2014); indeed, the sooner PML is recognized, the therapy stopped, and plasma exchange initiated, the better the outcome (Chalkley and Berger, 2013). However, at present, there is no blood biomarker of JCV activity that can be used alone to diagnose PML, and a failure to detect JCV DNA in the cerebrospinal fluid (CSF) does not rule out the possibility of having PML, particularly in the earlier stages of the disease (Brew et al., 2010; Cordioli et al., 2014). The only humoral parameter obtained routinely is the JCV seropositivity status, which is evaluated by detecting antibodies directed against JCV VP1 (the main surface JCV protein) using the single validated STRATIFY JC virus ${ }^{\mathrm{TM}}$ assay (Gorelik et al., 2010; Bozic et al., 2011; Lee et al., 2013).This assay allows neurologists to detect patients at higher risk of developing PML. In particular, three factors-the presence of anti-JCV antibodies, with a lower risk of developing PML in patients with low antibody titers (Plavina et al., 2014), previous use of immunosuppressants, and protracted duration of treatment, especially if longer than 2 years-seem to contribute to the overall risk of natalizumab-associated PML (Bloomgren et al., 2012). Patients with all three risk factors are those at the greatest risk (Sandrock et al., 2011). However, although this risk-factor algorithm may help identifying patients for whom natalizumab is appropriate and may reduce the incidence of PML, its use has some limitations. For instance, because about $57.1 \%$ of MS patients are seropositive for JCV (a value very close to the $60 \%$ observed in the general population), whereas PML is a rare event, its usefulness in the stratification of patients at risk of PML is limited (Bozic et al., 2011; Lee et al., 2013; Bozic et al., 2014). Furthermore, it appears that the knowledge of these risk factors has not led to a reduction in the incidence of PML in natalizumab-treated patients. Indeed, from April 2010 to February 2014 the incidence of PML has remained essentially unchanged, regardless of natalizumab treatment duration (Cutter and Stüve, 2014; Biogen Idec. https://medinfo.biogenidec.com).

The other strategies commonly used for the diagnosis of natalizumabinduced PML, such as magnetic resonance imaging (MRI) (Vennegoor et al., 2011; Ayzenberg et al., 2012), quantitative polymerase chain reaction (PCR) for detection of JCV DNA in CSF (Kappos et al., 2011; Mentzer et al., 2012; Berger et al., 2013), and JCV antibody index in CSF, which measures intrathecal synthesis of anti-JCV antibodies (Warnke et al., 2014), at present, do not appear to be useful as biomarkers predictive of PML risk prior to therapy initiation.

\section{Proposed alternative, immunological markers predictive of natalizumab-related PML}

Besides a reduced immune surveillance, other host immune factors and modifications of immune-viral interplay may also play a role in PML development. Viral mutations, facilitating the infection of oligodendroglial cells, together with modifications of the immune system composition, appear to be required for latent JCV to become pathogenic (Weissert, 2011). Indeed, in natalizumab-treated patients, mutations in the coding regions of the viral capsid protein VP1 and in the non-coding control region of the virus (Reid et al., 2011) have been associated with PML. Furthermore, additional secondary effects of natalizumab on immune cells other than its ability to inhibit the crossing of the blood brain barrier have also been documented (Stüve, 2008; Koudriavtseva et al., 2014). Thus, alternative immunological markers helping in the identification of MS patients at risk of PML prior to initiation or during natalizumab therapy could be critical in guiding the decision to start or cease treatment.

This review will focus on analysis performed on peripheral blood samples, as reported below and in Table 1, because central nervous system (CNS) tissue cannot be routinely obtained for diagnostic purposes because of the potential adverse effects. Similarly, CSF, that may reflect cellular events within the parenchyma, although more easily accessible, cannot be considered the ideal biological material for the screening of natalizumab-treated patients at risk of PML.

\subsection{Anti-JCV neutralizing activity}

Very recently, a lack of a correlation between the level of anti-JCV antibodies and anti-JCV neutralizing activity was demonstrated, suggesting that the serum anti-JCV neutralizing activity could be better correlated to the actual risk of developing PML during natalizumab treatment (Diotti et al., 2014). This may possibly allow an improved risk stratification of natalizumab-treated patients.

\subsection{Individual genetic predisposition}

The risk of developing PML might critically depend on host genetic factors that establish the immune response to the JCV, and protect from its spread from the peripheral places of persistency or latency to the brain. By determining HLA-alleles with single-nucleotide polymorphism imputation, PCR amplification with sequence-specific primer kits, or with a reverse PCR sequence-specific oligonucleotide method, a strong association between class II gene variants and JCV infection was found in Scandinavian and German patients with MS and in Swedish controls (Sundqvist et al., 2014). In particular, alleles within the HLA-DRB $1 * 15$ haplotype appear to be associated with a protective effect 
Table 1

Proposed immunological biomarkers predicting PML.

\begin{tabular}{|c|c|c|c|}
\hline Marker & Method & Clinical interpretation & Reference \\
\hline Presence of anti-JCV neutralizing anitbodies & Neutralization assay on COS7 target cells & Needs clinical validation in PML cases & Diotti et al. (2014) \\
\hline HLA-DRB1*15/HLA-DQB1*06:03 & $\begin{array}{l}\text { PCR with SSP, reverse PCR SSO and SNP } \\
\text { microarray }\end{array}$ & $\begin{array}{l}\text { Associated respectively with decreased/ } \\
\text { increased JVC carriage susceptibility }\end{array}$ & Sundqvist et al. (2014) \\
\hline Decrease in iATP in $\mathrm{CD}^{+}{ }^{+} \mathrm{T}$ cells & Luciferase-activity based assay & Associated with $\mathrm{PML}^{\mathrm{a}}$, non-predictive & $\begin{array}{l}\text { Haghikia et al. (2011); } \\
\text { Goelz et al. (2011) }\end{array}$ \\
\hline Increase of IL- 10 production by $\mathrm{CD} 4^{+} \mathrm{T}$ cells & $\begin{array}{l}\text { IL- } 10^{+} \text {cells quantification by flow cytomerty } \\
\text { after antigenic stimulation in vitro }\end{array}$ & Associated with PML & Perkins et al. (2012) \\
\hline $\begin{array}{l}\text { Increased miRNA-320 and miRNA-320b plus } \\
\text { decreased miRNA-629 expression }\end{array}$ & Quantitative real time RT-PCR & Associated with PML & $\begin{array}{l}\text { Muñoz-Culla et al. } \\
\text { (2014) }\end{array}$ \\
\hline Reduced CD62L-expressing $\mathrm{CD}^{+}{ }^{+} \mathrm{T}$ cells & Flow cytometry & Predictive of $\mathrm{PML}^{\mathrm{b}}$ & Schwab et al. (2013) \\
\hline $\begin{array}{l}\text { Reduced CD62L-expressing CD4 }{ }^{+} \mathrm{T} \text { cells plus } \\
\text { anti-JCV antibody index positivity }\end{array}$ & Flow cytometry and ELISA & Predictive of PML & Schwab et al. (2014) \\
\hline $\begin{array}{l}\text { Decreased CD11a expression on } \mathrm{CD}^{+} \text {and } \\
\mathrm{CD}^{+} \mathrm{T} \text { cells }\end{array}$ & Flow cytometry & Predictive of PML, low sensitivity & $\begin{array}{l}\text { Jilek et al. (2014); } \\
\text { Schwab et al. (2013) }\end{array}$ \\
\hline $\begin{array}{l}\text { Decreased TRECs and increased KRECs } \\
\text { quantification }\end{array}$ & Quantitative real time PCR & Predictive of PML & Sottini et al. (2012) \\
\hline Reduced TCR repertoire diversity & CDR3 spectratyping & Predictive of PML & Sottini et al. (2012) \\
\hline
\end{tabular}

SNP: single-nucleotide polymorphism; SSP: sequence-specific primers; SSO: sequence specific oligonucleotide; and CDR3: complementarity determining region 3.

a Associated with PML: cross-sectional evidence only; still needs to be validated in longitudinal studies comparing pre vs. post PML samples.

b Predictive of PML: longitudinal studies comparing pre vs. post PML samples.

on JCV infection, while alleles within the $\mathrm{DQB} 1{ }^{*} 06: 03$ haplotype provide an opposite association. The authors suggest that $\mathrm{CD} 4^{+} \mathrm{T}$ cells, restricted by class II molecules, are crucial for the host control of JCV infection. This is of relevance, but it is necessary to remember that the DRB1*15DQA $1^{*} 01: 02-D Q B 1{ }^{*} 06: 02-$ haplotype is the most strongly associated MS genetic risk factor; therefore, based only on this feature, the majority of patients would turn out as good candidates for natalizumab. However, because the HLA-DRB1*15:01 haplotype was also associated to lower antibody levels, which, in turn, have been associated to a lower PML risk (Plavina et al., 2014), the test may be useful to identify-among all those who are anti-JCV seropositive-that smaller fraction of patients lacking the genetic feature who should be at increased risk, and, therefore, would deserve a closer monitoring. If future studies will yield additional evidences directly linking these haplotypes to PML incidence, the knowledge of the host genetic factors influencing the response to JCV might become of great help in identifying patients at a low risk of PML. This information could be easily obtained, considering that, with the advent of high-throughput genetic screening approaches, genetic data are being acquired in shorter times and at decreasing costs (Erlich, 2012).

\subsection{Bioenergetic values in immune cells}

JCV infection control involves the recognition of viral antigens by $\mathrm{CD}^{+}$lymphocytes carrying the "appropriate" HLA-class II molecules (Sundqvist et al., 2014), and the subsequent activation of cytotoxic $\mathrm{CD}^{+} \mathrm{T}$ cells. These activities are accompanied by phenotypic and functional modifications that require an enhanced supply of ATPgenerating metabolites to meet the increased bioenergetic demands (Fox et al., 2005). Intracellular CD4 ${ }^{+}$-ATP concentration (iATP) in phytohaemagglutinin-stimulated $\mathrm{CD}^{+}{ }^{+} \mathrm{T}$ cells of 16 patients with monoclonal antibodies-associated PML, including 8 treated with natalizumab, was reduced by $59 \%$ in comparison to healthy controls, with 14 patients with iATP levels at/or below 3rd percentile of healthy control values (Haghikia et al., 2011). While the authors of the study proposed that the measure of decreased iATP may assist in risk stratification and monitoring of patients under monoclonal antibody immunotherapy, this hypothesis is in conflict with other data demonstrating that patients who subsequently developed PML had iATP levels in the normal range and not differing from those of patients without PML (Goelz et al., 2011).

\subsection{IL-10 production by $C D 4^{+} T$ cells}

Some studies investigated whether JCV-specific T-cell responses in healthy donors and natalizumab-treated MS patients showed functional differences that could account for the development of natalizumabassociated PML. The measure of JCV-specific T-cell responses directed against the JCV VP1 protein by quantification of interferon gamma production yielded conflicting results when examining longitudinal T-cell responses to JCV in individuals with MS treated with natalizumab (Chen et al., 2009; jilek et al., 2010). Peripheral blood mononuclear cells of PML patients, when stimulated by anti-CD28 and anti-CD49d monoclonal antibodies, in the presence or absence of the Staphylococcus aureus enterotoxin B superantigen, did not show detectable T-cell responses to $\mathrm{JCV}$, or had JCV-specific $\mathrm{CD}^{+}{ }^{+} \mathrm{T}$-cell responses uniquely dominated by IL-10 production rather than interferon gamma (Perkins et al., 2012). Thus, because the production of IL-10 by JCVspecific $\mathrm{CD} 4^{+} \mathrm{T}$ cells may interfere with this antiviral activity to the detriment of JCV replication control, either locally in the CNS or in peripheral tissues, becoming causative of PML, the authors proposed the measure of IL-10 for the identification of patient prone to develop PML. Against this possibility are the findings that IL-10 production was not detected earlier than 4 months after the clinical onset of PML and that increased JCV-specific IL-10 production by peripheral blood mononuclear cells can be observed in HIV $^{+}$subjects with PML, but not in non-HIV PML cases (Weber et al., 2001).

\subsection{Blood microRNA expression pattern}

It has been recently demonstrated that natalizumab alters microRNA (miRNA) expression in B cells of MS patients (Sievers et al., 2012), and that expression levels of three miRNAs, namely let-7c, miR-125a-5p and miR-642, were modified after 6 months of therapy. Furthermore, the three miRNAs, miR-320, miR-320b and miR-629, which are differentially expressed in the PML and nonPML groups after 12 months of treatment, have been proposed as possible biomarkers for individual PML risk assessment (MuñozCulla et al., 2014). Although the lack of a longitudinal study on samples obtained before PML onset limits the significance of this study, these data could be of particular interest because more than one database predicts that miR-320 and miR-320b have putative binding sites in L-selectin, which probably is, at the present, one of the most promising immunological biomarker of PML development. 


\subsection{L-selectin (CD62L) percentage on $\mathrm{CD}^{+}{ }^{+} \mathrm{T}$ cells}

L-selectin, which acts as a "homing receptor" for lymphocytes to enter secondary lymphoid tissues via high endothelial venules, was evaluated in a study that included 289 subjects with MS; 224 patients had been treated for $18-80$ months with natalizumab, 21 had received glatiramer acetate or interferon beta, 28 were untreated MS subjects and 16 were natalizumab-treated patients that developed PML (Schwab et al., 2013). In eight of them, blood samples were available also prior to the diagnosis of PML and in three before natalizumab therapy initiation. In comparison with MS patients receiving glatiramer acetate or interferon beta and with healthy controls, patients long-term treated with natalizumab had a percentage of $\mathrm{CD} 4^{+} \mathrm{T}$ cells expressing L-selectin that was under the cut-off (established by subtracting 2 SD from the mean of the control cohort). The presence of a very low percentage of these cells was highly correlated with the risk of developing PML in the group with available pre-PML samples when compared with non-PML natalizumab-treated patients. These data demonstrated that the cell-based assessment of the percentage of L-selectin-expressing $\mathrm{CD}^{+}{ }^{+} \mathrm{T}$ cells has the possibility of providing a biomarker for an individualized natalizumab-related PML risk assessment, and perhaps also for HIV-associated PML risks (Schwab et al., 2013; Schneider-Hohendorf et al., 2014).

It has been calculated that the detection of anti-JCV antibodies alone determined $54.2 \%$ of the study cohort patients to be at risk of PML, while CD62L set the proportional risk at $6.6 \%$. A combination of the two parameters reduced the risk percentage to 4.4\% (Schwab et al., 2014). However, because a natalizumab-treated population usually has a risk of about 1 out of 300, probably most of these patients will never develop PML.

The major problem of L-selectin detection is related to the highly unstable ex-vivo expression of this molecule on the cell surface and to the difficulties in the standardization of staining protocols before flow cytometry analysis. Therefore, a rigorous setup of the technique and the use of a large number of controls would be recommended.

A sustained decrease of adhesion molecules involved in the leukocyte trafficking, alpha-4 and beta-1 integrin surface level in particular, was observed in T cells, B cells, natural killer cells, natural killer T cells, and dendritic cells (Wipfler et al., 2011; de Andrés et al., 2012; Harrer et al., 2012), but only CD11a expression after 2 years of natalizumab treatment, when PML incidence reaches its peak level, has been proposed as a PML biomarker (Jilek et al., 2014).

\subsection{Newly produced T and B lymphocytes and T-cell repertoire diversity}

It has been recently demonstrated that $\mathrm{CD} 34^{+}$progenitor cells, which may harbor JCV, are mobilized at high concentrations from bone marrow into the peripheral circulation by natalizumab (Zohren et al., 2008). A portion of these latently infected cells initiates its differentiation into $\mathrm{CD} 19^{+}$B lymphocytes, which can harbor the virus as well (Frohman et al., 2014). Starting from these findings, we investigated whether the drug also increases the release of newly produced $\mathrm{T}$ and $\mathrm{B}$ lymphocytes from thymus and bone marrow; to this end, we quantified T-cell receptor excision circles (TRECs) and K-deleting recombination excision circles (KRECs), which have been described as markers of new T- and B-cell release from their production sites (Sottini et al., 2010). We found that both TRECs and KRECs significantly increased in natalizumabtreated patients (Zanotti et al., 2012), excluding one patient who developed PML after 34 months of therapy. In this patient, on the contrary, who showed a very low number of TRECs ${ }^{+}$cells already before therapy initiation, natalizumab was not capable of increasing the thymic release of newly produced $T$ lymphocytes at any time of the analysis, which was performed in samples obtained at $6,12,15$ and 34 months of therapy. This reduced thymic output was confirmed by quantifying $\mathrm{CD} 4{ }^{+} \mathrm{CD} 45 \mathrm{RA}{ }^{+} \mathrm{CCR} 7{ }^{+} \mathrm{CD} 31^{+}$recent $\mathrm{T}$ emigrants by flow cytometry. In contrast, in the same patient, KRECs, which were also very low before the first natalizumab infusion, initially increased to reach the values observed in the other natalizumab-treated patients, but then decreased at the time of PML onset (Sottini et al., 2012).

A low level of TRECs, such as that found in untreated MS patients (Chiarini et al., 2010), can be one of the reasons for the limited T-cell receptor diversity commonly found in MS patients, who show several $\mathrm{T}$-cell receptor $\mathrm{V}$ beta family (TCRBV) clonal expansions, some of which long-lasting, in the blood, CSF or in brain lesions (Gran et al., 1998; Muraro et al., 2006; Junker et al., 2007). On the other hand, because of the increased thymic output associated to natalizumab therapy (Zanotti et al., 2012), one could expect a relative enlargement of T-cell diversity. This possibility has been tested by studying the TCRBV repertoire with a method called complementarity-determining region-3 (CDR3) spectratyping, which analyses the length distribution of the CDR3 regions of TCRBV families. In young healthy subjects, the distribution of CDR3 lengths in the various TCRBV families is "normal" or Gaussian-like (Zou et al., 2014) and is constant during time (Fig. 1A). Deviations from the Gaussian-like distribution in the spectratype profiles are indicative of either disappearance or expansion of individual T-cell clones. According to the initial hypothesis, the peripheral T-cell repertoire restrictions found in blood of MS patients appeared less prominent during therapy with natalizumab (Zanotti et al., 2012; Warnke et al., 2013), whereas, after natalizumab therapy discontinuation, this enlargement of the T-cell repertoire diversity promptly disappeared (Chiarini et al., in press). On the contrary, in the patient that developed PML after 34 months of therapy with natalizumab, who showed persistently low TREC levels in the presence of a normal number of KRECs, we found profound alterations in the TCRBV spectratype profiles. Deviations from the Gaussian-like distribution, presence of 1 or 2 dominant peaks, and absence of detectable peaks were observed in samples obtained before natalizumab therapy initiation, at 12 months of treatment and then at the moment of PML development (Fig. 1B) (Sottini et al., 2012). Therefore, we propose that in the presence of a long lasting decrease of TRECs and of restricted T-cell repertoires, occurring when the levels of KRECs increase, a natalizumab-treated patient could be considered at risk of PML.

In support of this hypothesis, it should be also taken into account that JCV mutations have been associated to PML in natalizumabtreated patients (Reid et al., 2011). In this context, a long lasting decrease of the thymic output, on one hand, depletes the peripheral T-cell compartment of the repertoire diversity necessary for an effective antigen recognition; on the other hand it increases repertoire restrictions in the CSF (Warnke et al., 2013). This would likely cause an impaired identification of JCV displaying mutated antigens carried by $\mathrm{CD} 4^{+}$progenitor cells and B lymphocytes mobilized by natalizumab (Zohren et al., 2008; Frohman et al., 2014).

Therefore, a quantification of TRECs and KRECs can be a potential tool to identify patients at risk of developing PML, but only if performed in longitudinal samples. Based on this and on previously published longitudinal studies, an updated, tentative risk-stratification algorithm would be to perform TREC and KREC quantification to follow up patients who can be considered at an intermediate risk, for example patients bearing only one of two well-consolidated highest-risk features, i.e. antibody positivity without a treatment duration longer than 24 months (Bloomgren et al., 2012), in particular if they also have lymphocytes with a low level of CD62L expression (Suppl. Fig. 1). This could be more feasibly done by setting-up an easier way of TREC and KREC detection, as that proposed for newborn screening (Borte et al., 2012). On the contrary, the currently available techniques for the analysis of T-cell diversity (Bolotin et al., 2012; Zanotti et al., 2012; Warnke et al., 2013), due to complexity and costs, cannot be used as a screening of patients at risk of PML, but can be a useful tool to confirm the immune defects caused by a long lasting decrease of TRECs. 
Ctrl TO

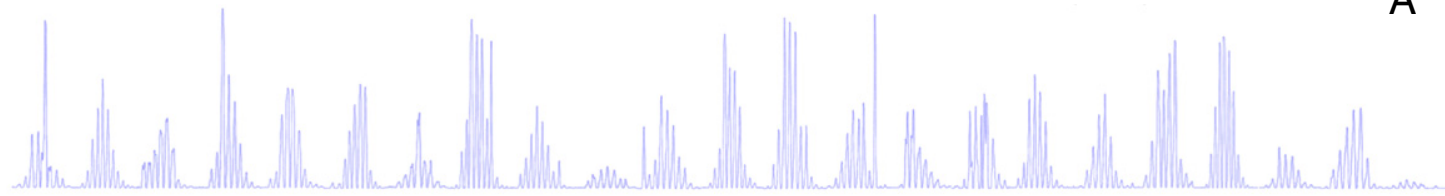

Ctrl T12

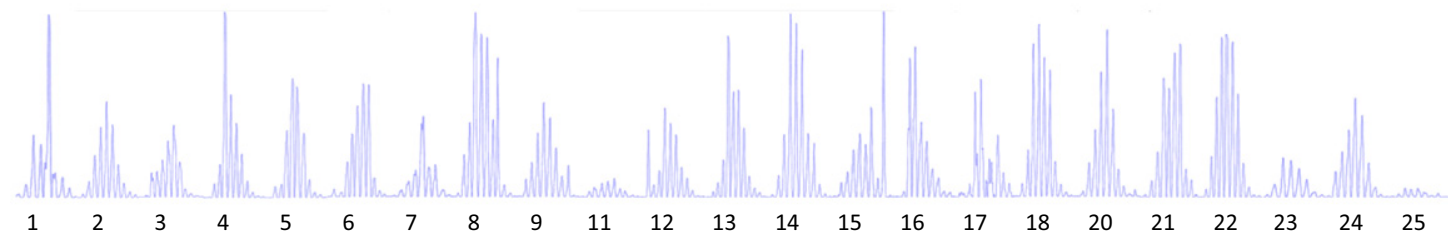

TO

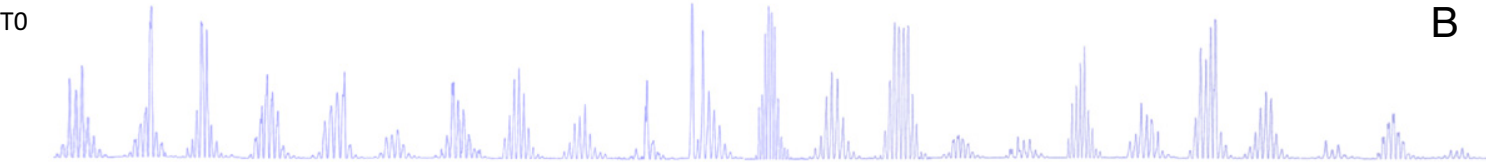

T12

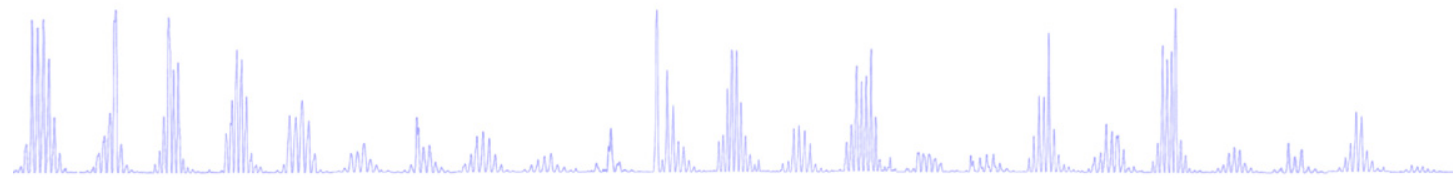

T34

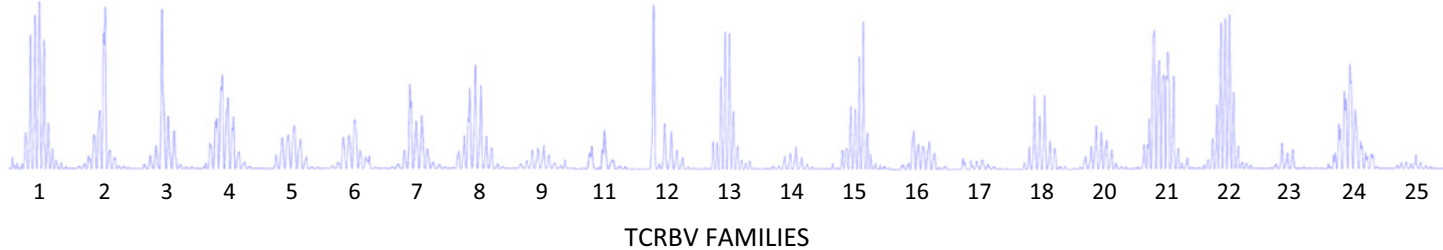

Fig. 1. Analysis of T-cell diversity. CDR3 size spectratyping measures CDR3 region length variations within each TCRBV gene family amplified by multiplex PCR (Zanotti et al., 2012; Warnke et al., 2013). (A) In a representative age-matched healthy control (Ctrl), because of the random generation of a very large number of T-cell receptors with unique CDR3 regions, the spectratype peaks of CDR3 region lengths follow, for the most part, bell-shaped curves with more than 7 peaks, corresponding to a Gaussian-like distribution, with only few peaks not fitting the normal distribution. The spectratyping of the same subject after 1 year (T12) is unchanged. (B) In an MS patient that developed PML after 34 months of natalizumab therapy, alterations of CDR3 profiles over time, including deviation from Gaussian-like distribution, presence of 1 or 2 dominant peaks, and lack of expected peaks (less than 7 peaks), were observed in several TCRBV families amplified starting from samples obtained before natalizumab therapy initiation (T0) and at 12 (T12) and 34 (T34) months of therapy.

\section{Conclusions}

In the last few years, several studies evaluating specific biomarkers for MS patients under natalizumab therapy have been carried out and their results show some potential to improve the safety and efficacy of the therapy. However, most of these studies included only a small number of patients, and therefore, no definitive conclusions can be drawn as to which are the most appropriate biomarkers to prevent PML onset. Furthermore, the complexity of the techniques used for identification of these biomarkers and the lack of method standardization currently limit their routine application. Consequently, any proposed, novel marker would require validation in multicenter clinical trials. Based on the available evidence indicating that PML risk markedly increases after 24 months of natalizumab treatment (Bloomgren et al., 2012), longitudinal studies of at least 36-48 months would be recommended to correctly define which markers have enough sensitivity in detecting the disease before its onset. The final scope would be to develop assays that may advise more rational therapy switches before reaching the high risk zone of 24 months of treatment.

Supplementary data to this article can be found online at http://dx. doi.org/10.1016/j.jneuroim.2014.10.011.

\section{References}

Ayzenberg, I., Lukas, C., Trampe, N., Gold, R., Hellwig, K., 2012. Value of MRI as a surrogate marker for PML in natalizumab long-term therapy. J. Neurol. 259, 1732-1733.
Berger, J.R., Aksamit, A.J., Clifford, D.B., Davis, L., Koralnik, I.J., Sejvar, J.J., Bartt, R., Major E.O., Nath, A., 2013. PML diagnostic criteria: consensus statement from the AAN Neuroinfectious Disease Section. Neurology 80, 1430-1438.

Bloomgren, G., Richman, S., Hotermans, C., Subramanyam, M., Goelz, S., Natarajan, A., Lee S., Plavina, T., Scanlon, J.V., Sandrock, A., Bozic, C., 2012. Risk of natalizumabassociated progressive multifocal leukoencephalopathy. N. Engl. J. Med. 366, 1870-1880.

Bolotin, D.A., Mamedov, I.Z., Britanova, O.V., Zvyagin, I.V., Shagin, D., Ustyugova, S.V., Turchaninova, M.A., Lukyanov, S., Lebedev, Y.B., Chudakov, D.M., 2012. Next generation sequencing for TCR repertoire profiling: platform-specific features and correction algorithms. Eur. J. Immunol. 42, 307-383.

Borte, S., von Döbeln, U., Fasth, A., Wang, N., Janzi, M., Winiarski, J., Sack, U., PanHammarström, Q., Borte, M., Hammarström, L., 2012. Neonatal screening for severe primary immunodeficiency diseases using high-throughput triplex real-time PCR Blood 119, 2552-2555.

Bozic, C., Richman, S., Plavina, T., Natarajan, A., Scanlon, J.V., Subramanyam, M., Sandrock, A., Bloomgren, G., 2011. Anti-John Cunnigham virus antibody prevalence in multiple sclerosis patients: baseline results of STRATIFY-1. Ann. Neurol. 70, 742-750.

Bozic, C., Subramanyam, M., Richman, S., Plavina, T., Zhang, A., Ticho, B., 2014. Anti-JC virus (JCV) antibody prevalence in the JCV Epidemiology in MS (JEMS) trial. Eur. J. Neurol. 21, 299-304.

Brew, B.J., Davies, N.W., Cinque, P., Clifford, D.B., Nath, A., 2010. Progressive multifocal leukoencephalopathy and other forms of JC virus disease. Nat. Rev. Neurol. 6 667-679.

Calabrese, L.H., Molloy, E.S., Huang, D., Ransohoff, R.M., 2007. Progressive multifocal leukoencephalopathy in rheumatic diseases: evolving clinical and pathologic patterns of disease. Arthritis Rheum. 56, 2116-2128.

Carson, K.R., Focosi, D., Major, E.O., Petrini, M., Richey, E.A., West, D.P., Bennett, C.L., 2009 Monoclonal antibody-associated progressive multifocal leucoencephalopathy in patients treated with rituximab, natalizumab, and efalizumab: a Review from the Research on Adverse Drug Events and Reports (RADAR) Project. Lancet Oncol. 10, 816-824.

Chalkley, J.J., Berger, J.R., 2013. Progressive multifocal leukoencephalopathy in multiple sclerosis. Curr. Neurol. Neurosci. Rep. 13, 408. 
Chen, Y., Bord, E., Tompkins, T., Miller, J., Tan, C.S., Kinkel, R.P., Stein, M.C., Viscidi, R.P., Ngo, L.H., Koralnik, I.J., 2009. Asymptomatic reactivation of JC virus in patients treated with natalizumab. N. Engl. J. Med. 361, 1067-1074.

Chiarini, M., Sottini, A., Ghidini, C., Zanotti, C., Serana, F., Rottoli, M., Zaffaroni, M., Bergamaschi, R., Cordioli, C., Capra, R., Imberti, L., 2010. Renewal of the T-cell compartment in multiple sclerosis patients treated with glatiramer acetate. Mult. Scler. $16,218-227$.

Chiarini, M., Sottini, A., Bertoli, D., Serana, F., Caimi, L., Rasia, S., Capra, R., Imberti, L., 2014 Newly produced T- and B-lymphocytes and T-cell receptor repertoire diversity are reduced in peripheral blood of fingolimod-treated multiple sclerosis patients. Mult Scler. http://dx.doi.org/10.1177/1352458514551456 (in press).

Clifford, D.B., De Luca, A., Simpson, D.M., Arendt, G., Giovannoni, G., Nath, A., 2010 Natalizumab-associated progressive multifocal leukoencephalopathy in patients with multiple sclerosis: lessons from 28 cases. Lancet Neurol. 9, 438-446.

Cordioli, C., De Rossi, N., Rasia, S., Lodoli, G., Capra, R., 2014. Early detection and favourable outcome of natalizumab-related progressive multifocal leukoencephalopathy (PML) in two multiple sclerosis patients. Neurol. Sci. http://dx.doi.org/10.1007/s10072014-1918-y (Epub ahead of print, Aug 11).

Cutter, G.R., Stüve, O., 2014. Does risk stratification decrease the risk of natalizumabassociated PML? Where is the evidence? Mult. Scler. 20, 1304-1305.

de Andrés, C., Teijeiro, R., Alonso, B., Sánchez-Madrid, F., Martínez, M.L., Guzmán de Villoria, J., Fernández-Cruz, E., Sánchez-Ramón, S., 2012. Long-term decrease in VLA-4 expression and functional impairment of dendritic cells during natalizumab therapy in patients with multiple sclerosis. PLoS One 7, e34103.

Diotti, R.A., Mancini, N., Clementi, N., Sautto, G., Moreno, G.J., Criscuolo, E., Cappelletti, F. Man, P., Forest, E., Remy, L., Giannecchini, S., Clementi, M., Burioni, R., 2014. Cloning of the first human anti-JCPyV/VP1 neutralizing monoclonal antibody: epitope definition and implications in risk stratification of patients under natalizumab therapy. Antivir. Res. 108, 94-103.

Erlich, H., 2012. HLA DNA typing: past, present, and future. Tissue Antigens 80, 1-11.

Fox, C.J., Hammerman, P.S., Thompson, C.B., 2005. Fuel feeds function: energy metabolism and the T-cell response. Nat. Rev. Immunol. 5, 844-852.

Frohman, E.M., Monaco, M.C., Remington, G., Ryschkewitsch, C., Jensen, P.N., Johnson, K Perkins, M., Liebner, J., Greenberg, B., Monson, N., Frohman, T.C., Douek, D., Major, E.O., 2014. JC virus in CD34 + and CD19+ cells in patients with multiple sclerosis treated with natalizumab. JAMA Neurol. 71, 596-602.

Goelz, S., Polman, C., Rudick, R., Kappos, L., Lublin, F., O'Connor, P., Goodman, A., Forrestal F., Duda, P., 2011. ImmuKnow (Cylex) does not appear to be useful for PML risk stratification with natalizumab treatment. Mult. Scler. 17, S507-S524.

Gorelik, L., Lerner, M., Bixler, S., Crossman, M., Schlain, B., Simon, K., Pace, A., Cheung, A Chen, L.L., Berman, M., Zein, F., Wilson, E., Yednock, T., Sandrock, A., Goelz, S.E., Subramanyam, M., 2010. Anti-JC virus antibodies: implications for PML risk stratification. Ann. Neurol. 68, 295-303.

Gran, B., Gestri, D., Sottini, A., Quiròs Roldàn, E., Bettinardi, A., Signorini, S., Primi, D. Ballerini, C., Taiuti, R., Amaducci, L., Massacesi, L., 1998. Detection of skewed T-cell receptor V-beta gene usage in the peripheral blood of patients with multiple sclerosis. J. Neuroimmunol. 85, 22-32.

Haghikia, A., Perrech, M., Pula, B., Ruhrmann, S., Potthoff, A., Brockmeyer, N.H., Goelz, S., Wiendl, H., Lindå, H., Ziemssen, T., Baranzini, S.E., Käll, T.B., Bengel, D., Olsson, T. Gold, R., Chan, A., 2011. Functional energetics of CD4+-cellular immunity in monoclonal antibody-associated progressive multifocal leukoencephalopathy in autoimmune disorders. PLoS One 6, e18506.

Harrer, A., Pilz, G., Einhaeupl, M., Oppermann, K., Hitzl, W., Wipfler, P., Sellner, J. Golaszewski, S., Afazel, S., Haschke-Becher, E. Trinka, E, Kraus, J. 2012. Lymphocyte subsets show different response patterns to in vivo bound natalizumab-a flow cytometric study on patients with multiple sclerosis. PLoS One 7, e31784.

Hou, J., Major, E.O., 2000. Progressive multifocal leukoencephalopathy: JC virus induced demyelination in the immune compromised host. J. Neurovirol. 6, S98-S100.

Jilek, S., Jaquiery, E., Hirsch, H.H., Lysandropoulos, A., Canales, M., Guignard, L., Schluep, M., Pantaleo, G., Du Pasquier, R.A., 2010. Immune responses to JC virus in patients with multiple sclerosis treated with natalizumab: a cross-sectional and longitudinal study. Lancet Neurol. 9, 264-272.

Jilek, S., Mathias, A., Canales, M., Lysandropoulos, A., Pantaleo, G., Schluep, M., Du Pasquier, R.A., 2014. Natalizumab treatment alters the expression of T-cell trafficking marker LFA-1 $\alpha$-chain (CD11a) in MS patients. Mult. Scler. 7, 837-842.

Junker, A., Ivanidze, J., Malotka, J., Eiglmeier, I., Lassmann, H., Wekerle, H., Meinl, E. Hohlfeld, R., Dornmair, K., 2007. Multiple sclerosis: T-cell receptor expression in distinct brain regions. Brain 130, 2789-2799.

Kappos, L., Bates, D., Edan, G., Eraksoy, M., Garcia-Merino, A., Grigoriadis, N., Hartung, H.P. Havrdová, E., Hillert, J., Hohlfeld, R., Kremenchutzky, M., Lyon-Caen, O., Miller, A. Pozzilli, C., Ravnborg, M., Saida, T., Sindic, C., Vass, K., Clifford, D.B., Hauser, S. Major, E.O., O'Connor, P.W., Weiner, H.L., Clanet, M., Gold, R., Hirsch, H.H., Radü, E.W., Sørensen, P.S., King, J., 2011. Natalizumab treatment for multiple sclerosis: updated recommendations for patient selection and monitoring. Lancet Neurol. 10, 745-758.

Karussis, D., 2013. Immunotherapy of multiple sclerosis: the state of the art. BioDrugs 27, 113-148.

Khalili, K., Safak, M., Del Valle, L., White, M.K., 2008. JC virus molecular biology and the human demyelinating disease, progressive multifocal leukoencephalopathy. In: Reiss, C.S. (Ed.), Neurotropic Virus Infections. Cambridge University Press, Cambridge, pp. 190-211.

Koudriavtseva, T., Sbardella, E., Trento, E., Bordignon, V., D'Agosto, G., Cordiali-Fei, P. 2014. Long-term follow-up of peripheral lymphocyte subsets in a cohort of multiple sclerosis patients treated with natalizumab. Clin. Exp. Immunol. 176, 320-326.

Lee, P., Plavina, T., Castro, A., Berman, M., Jaiswal, D., Rivas, S., Schlain, B., Subramanyam, M., 2013. A second-generation ELISA (STRATIFY JCVTM DxSelect ${ }^{\mathrm{TM}}$ ) for detection of
IC virus antibodies in human serum and plasma to support progressive multifocal leukoencephalopathy risk stratification. J. Clin. Virol. 57, 141-146.

Mentzer, D., Prestel, J., Adams, O., Gold, R., Hartung, H.P., Hengel, H., Kieseier, B.C., Ludwig, W.D., Keller-Stanislawski, B., 2012. Case definition for progressive multifocal leukoencephalopathy following treatment with monoclonal antibodies. J. Neurol. Neurosurg. Psychiatry 83, 927-933.

Muñoz-Culla, M., Irizar, H., Castillo-Triviño, T., Sáenz-Cuesta, M., Sepúlveda, L., Lopetegi, I., de Munain, A.L., Olascoaga, J., Baranzini, S., Otaegui, D., 2014. Blood miRNA expression pattern is a possible risk marker for natalizumab-associated progressive multifocal leukoencephalopathy in multiple sclerosis patients. Mult. Scler. http://dx.doi.org/10. 1177/1352458514534513 (Epub ahead of print, May 22).

Muraro, P.A., Cassiani-Ingoni, R., Chung, K., Packer, A.N., Sospedra, M., Martin, R., 2006. Clonotypic analysis of cerebrospinal fluid T cells during disease exacerbation and remission in a patient with multiple sclerosis. J. Neuroimmunol. 171, 177-183.

Perkins, M.R., Ryschkewitsch, C., Liebner, J.C., Monaco, M.C., Himelfarb, D., Ireland, S., Roque, A., Edward, H.L., Jensen, P.N., Remington, G., Abraham, T., Abraham, J., Greenberg, B., Kaufman, C., LaGanke, C., Monson, N.L., Xu, X., Frohman, E., Major, E.O., Douek, D.C., 2012. Changes in JC virus-specific T cell responses during natalizumab treatment and in natalizumab-associated progressive multifocal leukoencephalopathy. PLoS Pathog. 8, e1003014

Piccinni, C., Sacripanti, C., Poluzzi, E., De Ponti, F., 2013. Disproportionality signal of progressive multifocal leukoencephalopathy: monoclonal antibodies versus other immunosuppressants. Pharmacoepidemiol. Drug Saf. 22, 443-445.

Plavina, T., Subramanyam, M., Bloomgren, G., Richman, S., Pace, A., Lee, S., Schlain, B., Campagnolo, D., Belachew, S., Ticho, B., 2014. Anti-JC virus antibody levels in serum or plasma further define risk of natalizumab-associated progressive multifocal leukoencephalopathy. Ann. Neurol. (Epub ahead of print, Oct. 1).

Reid, C.E., Li, H., Sur, G., Carmillo, P., Bushnell, S., Tizard, R., McAuliffe, M., Tonkin, C., Simon, K., Goelz, S., Cinque, P., Gorelik, L., Carulli, J.P., 2011. Sequencing and analysis of JC virus DNA from natalizumab-treated PML patients. J. Infect. Dis. 204, 237-244.

Sandrock, A., Hotermans, C., Richman, S., Natarajan, A., Lee, S., Plavina, T., Bloomgren, G., Subramanyam, M., Bozic, C., 2011. Risk stratification for progressive multifocal leukoencephalopathy (PML) in MS patients: role of prior immunosuppressant use, natalizumab-treatment duration, and anti-JCV status. J. Neurol. 258, S23.

Schmedt, N., Andersohn, F., Garbe, E., 2012. Signals of progressive multifocal leukoencephalopathy for immunosuppressants: a disproportionality analysis of spontaneous reports within the US Adverse Event Reporting System (AERS). Pharmacoepidemiol. Drug Saf. 21, 1216-1220.

Schneider-Hohendorf, T., Philipp, K., Husstedt, I.W., Wiendl, H., Schwab, N., 2014. Specific loss of cellular L-selectin on CD4 + T cells is associated with progressive multifocal leukoencephalopathy development during HIV infection. AIDS 28, 793-795

Schwab, N., Schneider-Hohendorf, T., Posevitz, V., Breuer, J., Göbel, K., Windhagen, S., Brochet, B., Vermersch, P., Lebrun-Frenay, C., Posevitz-Fejfár, A., Capra, R., Imberti, L., Straeten, V., Haas, J., Wildemann, B., Havla, J., Kümpfel, T., Meinl, I., Niessen, K., Goelz, S., Kleinschnitz, C., Warnke, C., Buck, D., Gold, R., Kieseier, B.C., Meuth, S.G., Foley, J., Chan, A., Brassat, D., Wiendl, H., 2013. L-selectin is a possible biomarker for individual PML risk in natalizumab-treated MS patients. Neurology 81, 865-871.

Schwab, N., Schneider-Hohendorf, T., Breuer, J., Posevitz-Fejfar, A., Wiendl, H., PosevitzFejfar, A., 2014. Comparison and correlation of two proposed PML risk stratification biomarkers for long-term Natalizumab treatment, anti-JCV antibody index and L-selection (CD62L): a retrospective study. Neurology 83, e39.

Sievers, C., Meira, M., Hoffmann, F., Fontoura, P., Kappos, L., Lindberg, R.L., 2012. Altered microRNA expression in B lymphocytes in multiple sclerosis: towards a better understanding of treatment effects. Clin. Immunol. 144, 70-79.

Sottini, A., Ghidini, C., Zanotti, C., Chiarini, M., Caimi, L., Lanfranchi, A., Moratto, D., Porta, F., Imberti, L., 2010. Simultaneous quantification of recent thymic T-cell and bone marrow B-cell emigrants in patients with primary immunodeficiency undergone to stem cell transplantation. Clin. Immunol. 136, 217-227.

Sottini, A., Capra, R., Zanotti, C., Chiarini, M., Serana, F., Ricotta, D., Caimi, L., Imberti, L., 2012. Pre-existing $\mathrm{T}$ - and B-cell defects in one progressive multifocal leukoencephalopathy patient. PLoS One 7, e34493.

Stüve, O., 2008. The effects of natalizumab on the innate and adaptive immune system in the central nervous system. J. Neurol. Sci. 274, 39-41.

Sundqvist, E., Buck, D., Warnke, C., Albrecht, E., Gieger, C., Khademi, M., Lima Bomfim, I., Fogdell-Hahn, A., Link, J., Alfredsson, L., Søndergaard, H.B., Hillert, J., International Multiple Sclerosis Genetics Consortium, Oturai, A.B., Hemme, B., Kockum, I., Olsson, T., 2014. JC polyomavirus infection is strongly controlled by human leucocyte antigen class II variants. PLoS Pathog. 10, e1004084.

Tan, C.S., Koralnik, I.J., 2010. Progressive multifocal leukoencephalopathy and other disorders caused by JC virus: clinical features and pathogenesis. Lancet Neurol. 9, 425-437.

The IFNB Multiple Sclerosis Study Group, 1993. Interferon beta-1b is effective in relapsing-remitting multiple sclerosis. I. Clinical results of a multicenter, randomized, double-blind, placebo-controlled trial. Neurology 43, 655-661.

Vennegoor, A., Wattjes, M.P., van Munster, E.T., Kriekaart, R.L., van Oosten, B.W., Barkhof, F., Killestein, J., Polman, C.H., 2011. Indolent course of progressive multifocal leukoencephalopathy during natalizumab treatment in MS. Neurology 76, 574-576.

Warnke, C., Mausberg, A.K., Stettner, M., Dehmel, T., Nekrich, L., Meyer zu Horste, G., Hartung, H.P., Fogdell-Hahn, A., Adams, O., Kieseier, B.C., 2013. Natalizumab affects the T-cell receptor repertoire in patients with multiple sclerosis. Neurology 81, $1400-1408$.

Warnke, C., von Geldern, G., Markwerth, P., Dehmel, T., Hoepner, R., Gold, R., Pawlita, M., Kümpfel, T., Mäurer, M., Stangel, M., Wegner, F., Hohlfeld, R., Straeten, V., Limmroth, V., Weber, T., Hermsen, D., Kleinschnitz, C., Hartung, H.P., Wattjes, M.P., Svenningson, A., Major, E., Olsson, T., Kieseier, B.C., Adams, O., 2014. Cerebrospinal fluid JC virus antibody index for diagnosis of natalizumab-associated progressive multifocal 
leukoencephalopathy. Ann. Neurol. http://dx.doi.org/10.1002/ana.24153 (Epub ahead of print, Apr 11)

Wattjes, M.P., Vennegoor, A., Mostert, J., van Oosten, B.W., Barkhof, F., Killestein, J., 2014 Diagnosis of asymptomatic natalizumab-associated PML: are we between a rock and a hard place? J. Neurol. 261, 1139-1143.

Weber, F., Goldmann, C., Krämer, M., Kaup, F.J., Pickhardt, M., Young, P., Petry, H., Weber, T., Lüke, W., 2001. Cellular and humoral immune response in progressive multifocal leukoencephalopathy. Ann. Neurol. 49, 636-642.

Weissert, R., 2011. Progressive multifocal leukoencephalopathy. J. Neuroimmunol. 231, 73-77.

Wingerchuk, D.M., Carter, J.L., 2014. Multiple sclerosis: current and emerging diseasemodifying therapies and treatment strategies. Mayo Clin. Proc. 89, 225-240.

Wipfler, P., Oppermann, K., Pilz, G., Afazel, S., Haschke-Becher, E., Harrer, A., Huemer, M., Kunz, A., Golaszewski, S., Staffen, W., Ladurner, G., Kraus, J., 2011. Adhesion molecules are promising candidates to establish surrogate markers for natalizumab treatment. Mult. Scler. 17, 16-23.

Zanotti, C., Chiarini, M., Serana, F., Sottini, A., Garrafa, E., Torri, F., Caimi, L., Rasia, S., Capra, R., Imberti, L., 2012. Peripheral accumulation of newly produced T and B lymphocytes in natalizumab-treated multiple sclerosis patients. Clin. Immunol. 145, 19-26.

Zohren, F., Toutzaris, D., Klärner, V., Hartung, H.P., Kieseier, B., Haas, R., 2008. The monoclonal anti-VLA-4 antibody natalizumab mobilizes $\mathrm{CD} 34^{+}$hematopoietic progenitor cells in humans. Blood 111, 3893-3895.

Zou, H.Y., Yu, W.Z., Zhang, Q., Yang, H.C., Huang, H.Y., Jiao, M., 2014. Preliminary study of the clonal characteristics of the TCRBV subfamilies in T cells in the peripheral blood from patients with uveitis. Genet. Mol. Res. 13, 1296-1303. 